\title{
Synthesis of substituted meso-tetraphenylporphyrins in mixed solvent systems
}

\author{
Zhicheng Sun, ${ }^{a, b}$ Yuanbin She,,${ }^{a, *}$ Meijuan Cao, ${ }^{a}$ Qing Zhou, ${ }^{b}$ Xingmei Lu ${ }^{b^{*}}$ \\ and Suojiang Zhang ${ }^{\mathrm{b}}$ \\ ${ }^{a}$ Institute of Green Chemistry and Fine Chemicals, Beijing University of Technology, 100124 \\ Beijing, PR China \\ ${ }^{\mathrm{b}}$ Beijing Key Laboratory of Ionic Liquids Clean Process, Key Laboratory of Green Process and \\ Engineering, State Key Laboratory of Multiphase Complex Systems, Institute of Process \\ Engineering, Chinese Academy of Sciences, 100190 Beijing, PR China \\ E-mail: sheyb@bjut.edu.cn, xmlu@home.ipe.ac.cn
}

\begin{abstract}
An efficient synthetic method of substituted meso-tetraphenylporphyrins with better isolated yields was proposed by using propionic acid, valeric acid and $m$-nitrotoluene as mixed-solvent systems. The porphyrin yields in mixed solvent systems were obviously higher than those in the single propionic acid or valeric acid as solvents. The further investigation showed that the acidity, polarity, viscosity and the property of oxidant played an important role to the synthesis of porphyrin. Compared with other oxidants, $m$-nitrotoluene as an excellent oxidant could completely transform tetraphenylporphyrinogen to tetraphenylporphyrin.
\end{abstract}

Keywords: Porphyrin, synthesis, mixed solvents, oxidant

\section{Introduction}

meso-Tetraphenylporphyrin $\left(\mathrm{TPPH}_{2}\right)$ as one of the simple and stable substituted tetrapyrrolic macrocycle compounds has been widely investigated in terms of synthesis and application ${ }^{1-6}$ for several decades. Many porphyrin derivatives including free base porphyrin compounds with different substituents, ${ }^{7}$ mononuclear metalloporphyrins ${ }^{8}$ and binuclear metalloporphyrins ${ }^{9}$ have been prepared by virtue of the efficient synthesis of $\mathrm{TPPH}_{2}$ with high yields. They can be used to mimic natural enzyme peroxidase, catalase and heme-containing proteins, ${ }^{10}$ which are responsible for molecular binding, ${ }^{11}$ oxygen transport ${ }^{12}$ and energy transfer. ${ }^{13}$ The importance of $\mathrm{TPPH}_{2}$ synthesis as a methodology has been described in many literatures. ${ }^{14-16}$ 
Almost all of the natural and synthetic porphyrins can be synthesized by means of the cyclocondensation of substituted aldehydes with pyrrole and herein several famous synthetic methods have been widely established to synthesize $\mathrm{TPPH}_{2}$. Rothemund firstly synthesized $\mathrm{TPPH}_{2}$ in $10 \%$ yield by heating the mixture of pyrrole and benzaldehyde with pyridine as solvent in a sealed tube filled with nitrogen. ${ }^{17,18}$ Subsequently, Adler and Longo converted benzaldehyde and pyrrole to $\mathrm{TPPH}_{2}$ in a single refluxing carboxylic acid with air oxidation. ${ }^{19}$ The yield of $\mathrm{TPPH}_{2}$ was up to $20 \%$ and the separation of product was relatively simple by using Adler-Longo methodology. $^{20,21}$ Furthermore, Lindsey developed another synthetic strategy to form tetraphenylporphyrinogen by reacting benzaldehyde and pyrrole with dichloromethane as a solvent and $\mathrm{BF}_{3}$ etherate as a catalyst under $\mathrm{N}_{2}$ at room temperature. ${ }^{22}$ Then the tetraphenylporphyrinogen was transformed to $\mathrm{TPPH}_{2}$ with the addition of 2,3-dichloro-5,6dicyanobenzoquinone (DDQ) as a oxidant ${ }^{23}$ and the better spectroscopic yield of porphyrin was obtained with the addition of salts. ${ }^{24}$ Besides, $\mathrm{TPPH}_{2}$ might also be synthesized by the direct condensation of benzaldehyde and pyrrole with $\mathrm{AlCl}_{3}$ as the catalyst in refluxing DMF and the separation yield was $\sim 30 \%{ }^{25}$ In addition, tetraarylporphyrins could be obtained from pyrrole and substituted benzaldehydes in the gas phase without solvents ${ }^{26,27}$ or using high-valent transition metal salts as aromatizing agents to synthesize porphyrins. ${ }^{28}$ Guo and co-workers developed the industrial method and the device to synthesize tetraaryl porphyrins by using the condensation of pyrrole and aromatic aldehyde with air oxidation. ${ }^{29}$ Gonsalves et al used the mixture of acetic acid and nitrobenzene to synthesize $\mathrm{TPPH}_{2}$ in an aerated solution, and that the nitrobenzene played a role of oxidant. ${ }^{30-32}$ Above all, the synthetic methods of $\mathrm{TPPH}_{2}$ in the single solvent or solvent-free systems have been widely developed in recent years. ${ }^{33-35}$ However, the present synthesis of $\mathrm{TPPH}_{2}$ from the direct condensation of benzaldehyde and pyrrole is still inconvenient and the purity of products directly separated from the filtrate remains to be improved.

In our previous reports, ${ }^{36,37}$ the synthesis of para-substituted tetraphenylporphyrins with the mixed-solvent method was developed on the research basis of Gonsalves. ${ }^{30}$ In this paper, the mixed solvent systems of binary carboxylic acids and nitrobenzene derivatives were used to synthesize $\mathrm{TPPH}_{2}$ by the condensation of substituted benzaldehydes and pyrrole. By adjusting the physicochemical properties and oxidizing intensities of the reaction systems, the synthetic processes of $\mathrm{TPPH}_{2}$ became very effective and simple and that the better yields were obtained.

\section{Results and Discussion}

\section{Synthesis of $\mathbf{T P P H}_{2}$ in mixed solvent systems}

In an attempt to examine the effect of carboxylic acids on the synthesis of $\mathrm{TPPH}_{2}$, the condensation reaction in the single $\mathrm{C} 1-\mathrm{C} 8$ saturated fatty acids with different physicochemical parameters was performed. The results were listed in Table 1. 
Table 1. Yields of $\mathrm{TPPH}_{2}$ in the single carboxylic acids ${ }^{\mathrm{a}}$

\begin{tabular}{cccccc}
\hline Carboxylic acids & $\mathrm{p} K_{\mathrm{a}}^{\mathrm{b}}$ & $\begin{array}{c}\mu\left(30^{\circ} \mathrm{C},\right. \\
\mathrm{D})^{\mathrm{c}}\end{array}$ & $\begin{array}{c}\text { Refluxing } \\
\text { temperature }\left({ }^{\circ} \mathrm{C}\right)\end{array}$ & $\begin{array}{c}\text { Viscosities } \\
\left(30{ }^{\circ} \mathrm{C}, \mathrm{cps}\right)\end{array}$ & $\begin{array}{c}\text { Isolated } \\
\text { yields }(\%)\end{array}$ \\
\hline formic acid & 3.77 & 1.82 & 101 & 1.44 & 0 \\
acetic acid & 4.76 & 1.68 & 118 & 1.04 & 20.2 \\
propionic acid & 4.88 & 1.68 & 141 & 0.96 & 18.8 \\
butyric acid & 4.82 & 1.65 & 163 & 1.39 & 20.4 \\
valeric acid & 4.81 & 2.66 & 186 & 1.77 & 22.5 \\
hexanoic acid & 4.84 & 1.13 & 206 & 2.51 & 14.1 \\
heptanoic acid & 4.89 & 1.14 & 223 & 3.84 & 8.5 \\
octanoic acid & 4.85 & 1.15 & 237 & 4.69 & 3.4 \\
\hline
\end{tabular}

${ }^{a}$ Each reaction was performed via aerobic oxidation at $0.1 \mathrm{M}$ benzaldehyde and $0.1 \mathrm{M}$ pyrrole in $100 \mathrm{~mL}$ carboxylic acids under reflux for $2 \mathrm{~h} .{ }^{\mathrm{b}}$ Acid strength. ${ }^{\mathrm{c}}$ Dipole moment.

From Table 1, it could be seen that the isolated yields of $\mathrm{TPPH}_{2}$ were obtained in the range of $0-22.5 \%$ in the single carboxylic acids with air as the oxidant. It was found that $\mathrm{TPPH}_{2}$ was difficult to form in the strongest formic acid ( $\left.\mathrm{p} K_{\mathrm{a}}=3.77\right)$, however, the highest yield (22.5\%) of $\mathrm{TPPH}_{2}$ was obtained in valeric acid with the highest dipole moment $(\mu=2.66)$ and the stronger acid strength $\left(\mathrm{p} K_{\mathrm{a}}=4.81\right)$ than other carboxylic acids. Meanwhile, the yields of $\mathrm{TPPH}_{2}$ in single C2-C5 carboxylic acids (high polarity, moderate refluxing temperature and viscosity) were higher than those in C6-C8 carboxylic acids. The results indicated that the physicochemical properties of carboxylic acids had influences on the synthetic yields of $\mathrm{TPPH}_{2}$.

To further evaluate the roles of physicochemical parameters of carboxylic acids, binary carboxylic acids including valeric acid via aerobic oxidation were mixed and applied to the synthesis of $\mathrm{TPPH}_{2}$ and the results were listed in Table 2.

Table 2. Yields of $\mathrm{TPPH}_{2}$ in binary mixed carboxylic acids ${ }^{\mathrm{a}}$

\begin{tabular}{cccccc}
\hline Mixed carboxylic acids & $\mathrm{p} K_{\mathrm{a}}^{\mathrm{b}}$ & $\begin{array}{c}\mu(30 \\
\left.{ }^{\circ} \mathrm{C}, \mathrm{D}\right)\end{array}$ & $\begin{array}{c}\text { Refluxing } \\
\text { temperature } \\
\left({ }^{\circ} \mathrm{C}\right)\end{array}$ & $\begin{array}{c}\text { Viscosities } \\
\left(30{ }^{\circ} \mathrm{C}, \mathrm{cps}\right)\end{array}$ & $\begin{array}{c}\text { Isolated } \\
\text { yields }(\%)\end{array}$ \\
\hline formic acid : valeric acid & 4.29 & 2.24 & 118 & 1.61 & 0 \\
acetic acid : valeric acid & 4.79 & 2.17 & 128 & 1.41 & 23.4 \\
propionic acid : valeric acid & 4.85 & 2.17 & 152 & 1.37 & 28.2 \\
butyric acid : valeric acid & 4.82 & 2.16 & 164 & 1.58 & 24.6 \\
hexanoic acid : valeric acid & 4.83 & 1.90 & 186 & 2.14 & 20.3 \\
heptanoic acid : valeric acid & 4.85 & 1.90 & 190 & 2.81 & 13.5 \\
octanoic acid : valeric acid & 4.83 & 1.91 & 194 & 3.23 & 10.2 \\
\hline
\end{tabular}

${ }^{\mathrm{a}}$ Each reaction was performed via aerobic oxidation at $0.1 \mathrm{M}$ benzaldehyde and $0.1 \mathrm{M}$ pyrrole in $100 \mathrm{~mL}$ solvents $(\mathrm{V} / \mathrm{V}=1 / 1)$ under reflux for $2 \mathrm{~h} .{ }^{\mathrm{b}}$ Acid strength. ${ }^{\mathrm{c}}$ Dipole moment. 
As shown in Table 2, the synthesis in propionic acid - valeric acid mixed solvents with medium dipole moment and moderate refluxing temperature gave higher porphyrin yields than the corresponding synthesis in the single valeric acid or other binary mixed carboxylic acid systems. Therefore, the yields became higher in the given solvent compositions, which exhibited a lower viscosity and higher temperature. In addition, the yields in $\mathrm{C} 2-\mathrm{C} 4$ mixed carboxylic acid systems were higher than those in C6-C8 carboxylic acid combinations. The acids (including Lewis acid and Brønsted acid), as reported, ${ }^{31}$ played a catalytic role in the condensation of benzaldehyde and pyrrole. ${ }^{38}$ But then the stronger acidity was liable to make pyrrole form straight-chain pyrrole polymers, ${ }^{39}$ thus, almost all black intractable mixtures but the $\mathrm{TPPH}_{2}$ product were obtained in formic acid and valeric acid as the mixed solvents.

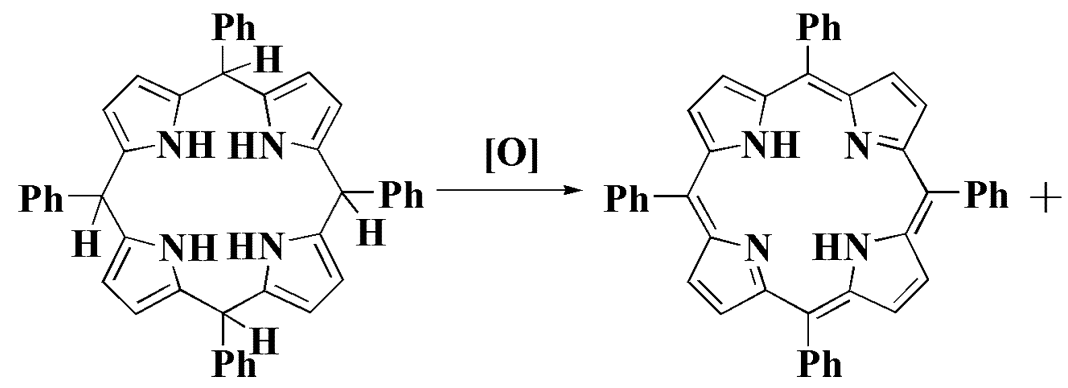

Tetraphenylporphyrinogen
Tetraphenylporphyrin

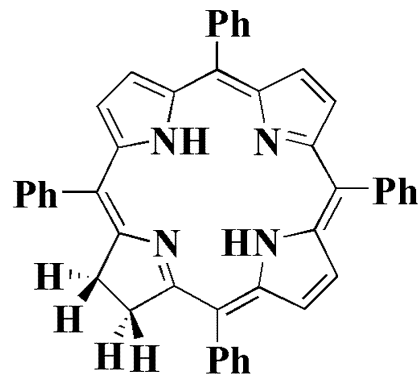

Tetraphenylchlorin

Scheme 1. Oxidation of tetraphenylporphyrinogen to tetraphenylporphyrin.

It is widely accepted that tetraphenylporphyrinogen is the key intermediate in the synthesis of tetraphenylporphyrin. The oxidation of tetraphenylporphyrinogen by $\mathrm{O}_{2}$ in the atmosphere (Scheme 1) $)^{15,23}$ was a competitive procedure which formed the desired porphyrin $\left(\mathrm{TPPH}_{2}\right)$ and tetraphenylchlorin (TPC). ${ }^{19}$ Hence, the oxidants played a crucial role in the synthesis of porphyrins and an ideal oxidant would selectively oxidize only tetraphenylporphyrinogen to $\mathrm{TPPH}_{2}$ without the formation of TPC. ${ }^{33,40}$ The results of reactions oxidized by different oxidants under the same conditions were listed in Table 3.

The results in Table 3 showed that the tetraphenylporphyrinogen oxidized by nitrobenzene derivatives gave better yields than those by air and dimethylsulfoxide. According to the UV-vis absorption spectra (Figure 1), the ratios of absorbances with nitrobenzene and air as oxidants between $\sim 480 \mathrm{~nm}$ and $\sim 650 \mathrm{~nm}$ was $1(0.064 / 0.064)$ and $1.26(0.111 / 0.088)$, which suggested the obtained porphyrin filtered from the reaction solution containing nitrobenzene was very pure without the formation of TPC. ${ }^{41}$ But the tetraphenylporphyrinogen was incompletely oxidized to $\mathrm{TPPH}_{2}$ only by $\mathrm{O}_{2}$ in the atmosphere if no stoichiometric oxidants were added into the reaction system. Nitrobenzene derivatives as the weak organic oxidants effectively promoted the formation of $\mathrm{TPPH}_{2}$, which had the same effect as dihydroquinoline oxidized to quinoline by nitrobenzene under acidic conditions in the Skraup reaction. ${ }^{42}$ Meanwhile, the yields of $\mathrm{TPPH}_{2}$ with nitrotoluene derivatives as oxidants were higher than those with nitrobenzene and 
nitrobenzoic acid derivatives as oxidants. Additionally, nitrotoluene derivatives were of lower toxicities versus nitrobenzene and the oxidative effect of $m$-nitrotoluene surpassed $o / p$ nitrotoluene in the synthesis of $\mathrm{TPPH}_{2}$. Thereby, $m$-nitrotoluene was chosen as a preferable oxidant in the synthesis of $\mathrm{TPPH}_{2}$.

Table 3. Effects of various oxidants on yields of $\mathrm{TPPH}_{2}{ }^{\mathrm{a}}$

\begin{tabular}{cccc}
\hline Oxidants & $\begin{array}{c}\text { Oxidant } \\
\text { concentrations }(\mathrm{M})\end{array}$ & Oxidant dosages & $\begin{array}{c}\text { Isolated yields } \\
(\%)\end{array}$ \\
\hline air & - & - & 28.2 \\
nitrobenzene & 0.25 & $2.5 \mathrm{~mL}(\mathrm{l})^{\mathrm{b}}$ & 35.5 \\
$o$-nitrotoluene & 0.25 & $3 \mathrm{~mL}(\mathrm{l})$ & 38.2 \\
$m$-nitrotoluene & 0.25 & $3 \mathrm{~mL}(\mathrm{l})$ & 41.5 \\
$p$-nitrotoluene & 0.25 & $3.4 \mathrm{~g}(\mathrm{~s})^{\mathrm{c}}$ & 37.3 \\
$o$-nitrobenzoic acid & 0.25 & $4.1 \mathrm{~g}(\mathrm{~s})$ & 30.5 \\
$m$-nitrobenzoic acid & 0.25 & $4.1 \mathrm{~g}(\mathrm{~s})$ & 33.5 \\
$p$-nitrobenzoic acid & 0.25 & $4.1 \mathrm{~g}(\mathrm{~s})$ & 31.4 \\
dimethylsulfoxide & 0.25 & $1.8 \mathrm{~mL}(\mathrm{l})$ & 18.9 \\
\hline
\end{tabular}

${ }^{\text {a }}$ Each reaction was performed at $0.1 \mathrm{M}$ benzaldehyde and $0.1 \mathrm{M}$ pyrrole in $100 \mathrm{~mL}$ solvents $\left(\mathrm{V}_{\text {propionic acid }}: \mathrm{V}_{\text {valeric acid }}=1: 1\right)$ under reflux for $2 \mathrm{~h} .{ }^{\mathrm{b}}$ Liquid. ${ }^{\mathrm{c}}$ Solid.

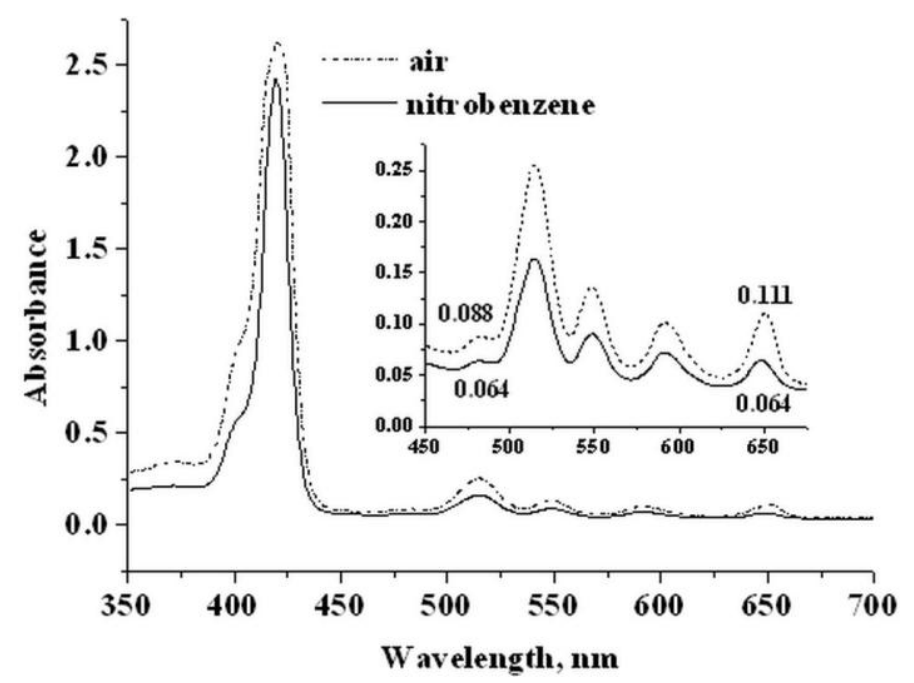

Figure 1. UV-vis absorbance spectra (benzene) of $\mathrm{TPPH}_{2}$ filtrated from the reaction solution with air and nitrobenzene as oxidants. 
Table 4. Effects of $m$-nitrotoluene concentrations and solvent proportions on yields of $\mathrm{TPPH}_{2}{ }^{\mathrm{a}}$

\begin{tabular}{ccc}
\hline $\begin{array}{c}m \text {-Nitrotoluene } \\
\text { concentrations (M) }\end{array}$ & $\mathrm{V}_{\text {propionic acid }}: \mathrm{V}_{\text {valeric acid }}: \mathrm{V}_{m \text {-nitrotoluene }}$ & Isolated yields $(\%)$ \\
\hline 0 & $50: 50: 0$ & 28.2 \\
0.17 & $49: 49: 2$ & 37.5 \\
0.34 & $48: 48: 4$ & 40.4 \\
\cline { 2 - 3 } 0.51 & $47: 47: 6$ & 45.1 \\
& $60: 34: 6$ & 39.1 \\
0.68 & $34: 60: 6$ & 42.5 \\
0.85 & $46: 46: 8$ & 41.2 \\
\hline
\end{tabular}

${ }^{\text {a }}$ Each reaction was performed at $0.1 \mathrm{M}$ benzaldehyde and $0.1 \mathrm{M}$ pyrrole in $100 \mathrm{~mL}$ solvents under reflux for $2 \mathrm{~h}$.

Now that the concentration of the oxidant usually had a profound effect on the synthetic reaction, the influences of $m$-nitrotoluene concentrations on the yields of $\mathrm{TPPH}_{2}$ were studied and the results were listed in Table 4 . In contrast to the $28.2 \%$ yield of $\mathrm{TPPH}_{2}$ without organic oxidants, the yield of $\mathrm{TPPH}_{2}$ exceeded $45 \%$ with $0.51 \mathrm{M}$ of $m$-nitrotoluene as the oxidant (Table 4). The results indicated the oxidation of tetraphenylporphyrinogen became gradually complete as the increase of $m$-nitrotoluene concentration. However, superfluous $m$-nitrotoluene (dipole moment, $4.21 \mathrm{D}$ ) affected the polarities of mixed solvent systems, so the yields of $\mathrm{TPPH}_{2}$ decreased gradually when the concentration of $m$-nitrotoluene exceeded $0.51 \mathrm{M}$. On the basis of the investigation of the optimal oxidants, the yields of $\mathrm{TPPH}_{2}$ in the mixed solvent systems with different proportions were examined. The highest yield (45.1\%) of $\mathrm{TPPH}_{2}$ was obtained by using propionic acid, valeric acid and $m$-nitrotoluene in the proportion of 47:47:6 (V/V/V) as the mixed solvent systems.

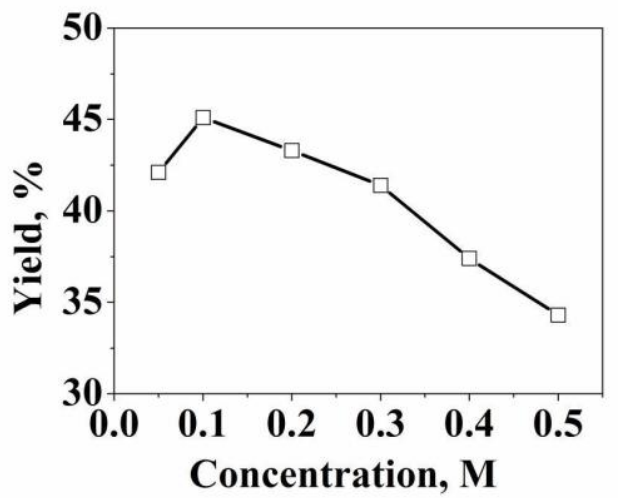

Figure 2. Effects of reactant concentrations on yields of $\mathrm{TPPH}_{2}$. Reaction conditions: equivalent molarities of benzaldehyde and pyrrole, $100 \mathrm{~mL}$ mixed solvent systems $\left(\mathrm{V}_{\text {propionic acid }} / \mathrm{V}_{\text {valeric }}\right.$ acid $/ \mathrm{V}_{m \text {-nitrotoluene }}=47 / 47 / 6$ ), reflux for $2 \mathrm{~h}$. 


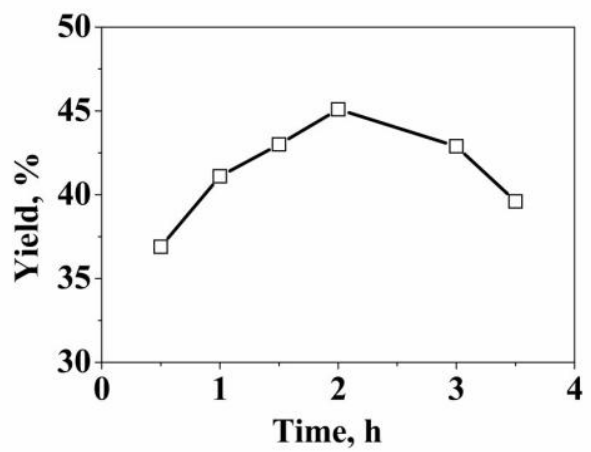

Figure 3. Effects of reaction time on yields of $\mathrm{TPPH}_{2}$. Reaction conditions: equivalent molarities of benzaldehyde $(0.1 \mathrm{M})$ and pyrrole $(0.1 \mathrm{M}), 100 \mathrm{~mL}$ mixed solvent systems $\left(\mathrm{V}_{\text {propionic acid }} / \mathrm{V}_{\text {valeric }}\right.$ acid $\left./ \mathrm{V}_{m \text {-nitrotoluene }}=47 / 47 / 6\right)$, under reflux conditions.

In addition, the reactant concentrations and reaction time also had obvious effects on the yields of $\mathrm{TPPH}_{2}$ in the mixed solvent systems of binary carboxylic acids and $m$-nitrotoluene (Figure 2 and Figure 3). Figure 2 showed that the yields of $\mathrm{TPPH}_{2}$ were closely related to the concentrations of reactants. The maximal yield was generally obtained at $0.1 \mathrm{M}$ of reactants and the reactions of higher concentrations gave lower yields than those in dilute solutions. As shown in Figure 3, the condensation rates of benzaldehyde and pyrrole in binary carboxylic acids and $m$-nitrotoluene as the mixed solvents were very fast and the yields of $\mathrm{TPPH}_{2}$ exceeded $35 \%$ in $0.5 \mathrm{~h}$. But the yields of $\mathrm{TPPH}_{2}$ gradually decreased when the reaction time was more than $2 \mathrm{~h}$ because of the polymerization of $\mathrm{TPPH}_{2}$ for long time at high temperature.

\section{Conclusions}

In summary, a synthesis of substituted tetraphenylporphyrins from aromatic aldehyde and pyrrole in binary carboxylic acids and nitrotoluene derivatives solvent systems was systematically studied. The highest yield of $\mathrm{TPPH}_{2}$ exceeded $45 \%$ with propionic acid, valeric acid and $m$-nitrotoluene as the mixed solvents. The improvement of the $\mathrm{TPPH}_{2}$ yields could be realized by adjusting the acidity, polarity, refluxing temperature and viscosity of mixed carboxylic acids. Nitrotoluene derivatives as oxidants played an important role in the synthesis of $\mathrm{TPPH}_{2}$ and $m$-nitrotoluene as an excellent oxidant exhibited remarkable effects in the oxidation of tetraphenylporphyrinogen. The experimental results showed that it was possible to apply binary carboxylic acid and nitrobenzene derivatives as the mixed solvents to synthesize various substituted tetraphenylporphyrins in excellent yields. 


\section{Experimental Section}

General. All chemicals were obtained commercially and used as received unless otherwise noted. Pyrrole was redistilled before use. Dichloromethane was dehydrated. Neutral $\mathrm{Al}_{2} \mathrm{O}_{3}$ was baked at $100{ }^{\circ} \mathrm{C}$ for $5 \mathrm{~h}$. Chromatography was performed on neutral $\mathrm{Al}_{2} \mathrm{O}_{3}$. Ultraviolet-visible (UV-vis) spectra were recorded in dichloromethane with a HITACHI U-3010 spectrophotometer. Infrared (IR) spectra were recorded as $\mathrm{KBr}$ pellets via a Nicolet AVATAR-360 spectrophotometer. 1H NMR spectra were recorded with an AV $400 \mathrm{MHz}$ Bruker spectrometer. The data of elemental analysis were obtained with an EURO EA3000 elemental analyzer.

\section{General synthetic procedures of $\mathbf{T P P H}_{2}$}

Propionic acid $(47 \mathrm{~mL})$ and valeric acid $(37 \mathrm{~mL})$ were added into a $250 \mathrm{~mL}$ three-neck roundbottom flask equipped with stirrer, reflux exchanger and dropping funnel. The mixture was stirred at refluxing temperature for $30 \mathrm{~min}$. Then, benzaldehyde $(1 \mathrm{~mL}, 0.01 \mathrm{~mol})$ was dissolved in valeric acid $(10 \mathrm{~mL})$ and freshly distilled pyrrole $(0.7 \mathrm{~mL}, 0.01 \mathrm{~mol})$ was dissolved in $\mathrm{m}$ nitrotoluene $(6 \mathrm{~mL})$. Subsequently, above two kinds of solutions were simultaneously dropped into the flask through two dropping funnels in $15 \mathrm{~min}$. The reaction mixture was stirred at refluxing temperature for $2 \mathrm{~h}$. When the temperature of the reaction mixture was cooled to 50 ${ }^{\circ} \mathrm{C}-60{ }^{\circ} \mathrm{C}$, methanol $(30 \mathrm{~mL})$ was added into the flask. After that, the reaction solution was allowed to stir for $15 \mathrm{~min}$ and then stood for $30 \mathrm{~min}$. The resulting solution was filtrated under reduced pressure and afforded the blue-purple power. The crude product was washed with methanol and dried in $60^{\circ} \mathrm{C}$ for 30 min. Purification by column chromatography $\left(\mathrm{Al}_{2} \mathrm{O}_{3}, \mathrm{CH}_{2} \mathrm{Cl}_{2}\right.$ as the eluent) afforded pure $\mathrm{TPPH}_{2}$. The isolated yield of the product was found to be $0.69 \mathrm{~g}$ (45.1\%). ${ }^{1} \mathrm{H} \mathrm{NMR}\left(\mathrm{CDCl}_{3} ; \mathrm{Me}_{4} \mathrm{Si}\right): \delta_{\mathrm{H}}-2.76(2 \mathrm{H}, \mathrm{s}$, pyrrole- $\mathrm{NH}), 7.74-7.78(12 \mathrm{H}, \mathrm{m}, \mathrm{Ph}), 8.21-$ $8.23(8 \mathrm{H}, \mathrm{m}, \mathrm{Ph}), 8.85$ (8H, s, $\beta$-pyrrole-H); UV-vis $\left(\mathrm{CH}_{2} \mathrm{Cl}_{2}\right): \lambda_{\max }, \mathrm{nm} 417,515,549,589,646$; IR(KBr): v, $\mathrm{cm}^{-1} 3314$ (w, NH), 1595 (w, C=C), 1349 (m, C=N), 965 (s, NH), 799 (s, CH); Anal. Calcd. for $\mathrm{C}_{44} \mathrm{H}_{30} \mathrm{~N}_{4}$ : C, 85.97; H, 4.92; N, 9.11; Found: C, 86.12; H, 5.11; N, 9.27.

$\mathbf{T}\left(\boldsymbol{p}-\mathbf{O C H}_{3}\right) \mathbf{P P H}_{2}$. $\mathrm{T}\left(p-\mathrm{OCH}_{3}\right) \mathrm{PPH}_{2}$ was synthesized by the same procedures as that descibed for $\mathrm{TPPH}_{2}$ and the final product was recrystallized from $\mathrm{CH}_{2} \mathrm{Cl}_{2}$ to yield $55.3 \%$. ${ }^{1} \mathrm{H} \mathrm{NMR}\left(\mathrm{CDCl}_{3}\right.$; $\left.\mathrm{Me}_{4} \mathrm{Si}\right): \delta_{\mathrm{H}}-2.74\left(2 \mathrm{H}, \mathrm{s}\right.$, pyrrole-NH), 4.03-4.10 $\left(12 \mathrm{H}, \mathrm{m}, \mathrm{OCH}_{3}\right), 7.26-7.30(8 \mathrm{H}, \mathrm{m}, \mathrm{Ph}), 8.11-$ $8.13(8 \mathrm{H}, \mathrm{m}, \mathrm{Ph}), 8.86\left(8 \mathrm{H}, \mathrm{s}, \beta\right.$-pyrrole-H); UV-vis $\left(\mathrm{CH}_{2} \mathrm{Cl}_{2}\right): \lambda_{\max }, \mathrm{nm} 421,518,555,593,650$; IR(KBr): v, $\mathrm{cm}^{-1} 3320$ (w, NH), 1596 (w, C=C), 1346 (m, C=N), 967 (s, NH), 805 (s, CH); Anal. Calcd. for $\mathrm{C}_{48} \mathrm{H}_{38} \mathrm{~N}_{4} \mathrm{O}$ : C, 78.54; H, 5.22; N, 7.63; Found: C, 78.80; H, 5.12; N, 7.72.

$\mathbf{T}\left(\boldsymbol{o}-\mathbf{O C H} \mathbf{C H}_{3}\right) \mathbf{P P H}_{2} \cdot \mathrm{T}\left(o-\mathrm{OCH}_{3}\right) \mathrm{PPH}_{2}$ was synthesized by the same procedures as that descibed for TPPH2 and the final product was recrystallized from $\mathrm{CH}_{2} \mathrm{Cl}_{2}$ to yield $25.4 \% .{ }^{1} \mathrm{H} \mathrm{NMR}\left(\mathrm{CDCl}_{3}\right.$; $\left.\mathrm{Me}_{4} \mathrm{Si}\right): \delta_{\mathrm{H}}-2.60(2 \mathrm{H}, \mathrm{s}$, pyrrole- $\mathrm{NH}), 3.57-3.63\left(12 \mathrm{H}, \mathrm{m}, \mathrm{OCH}_{3}\right), 7.32-7.36(8 \mathrm{H}, \mathrm{m}, \mathrm{Ph}), 7.75-$ $7.78(4 \mathrm{H}, \mathrm{m}, \mathrm{Ph}), 7.95-8.07(4 \mathrm{H}, \mathrm{m}, \mathrm{Ph}), 8.74\left(8 \mathrm{H}, \mathrm{s}, \beta\right.$-pyrrole-H); UV-vis $\left(\mathrm{CH}_{2} \mathrm{Cl}_{2}\right): \lambda_{\max }, \mathrm{nm}$ 417, 512, 545, 589, 643; IR(KBr): $v, \mathrm{~cm}^{-1} 3322(\mathrm{w}, \mathrm{NH}), 1580(\mathrm{w}, \mathrm{C}=\mathrm{C}), 1349(\mathrm{~m}, \mathrm{C}=\mathrm{N}), 966$ (s, $\mathrm{NH}), 753$ (s, CH); Anal. Calcd. for $\mathrm{C}_{48} \mathrm{H}_{38} \mathrm{~N}_{4} \mathrm{O}: \mathrm{C}, 78.54 ; \mathrm{H}, 5.22 ; \mathrm{N}, 7.63$; Found: C, 78.92; H, $5.51 ; \mathrm{N}, 7.89$. 
T(p-Cl)PPH . $\mathrm{T}(p-\mathrm{Cl}) \mathrm{PPH}_{2}$ was synthesized by the same procedures as that descibed for $\mathrm{TPPH}_{2}$ and the final product was recrystallized from $\mathrm{CH}_{2} \mathrm{Cl}_{2}$ to yield 50.3\%. ${ }^{1} \mathrm{H} \mathrm{NMR}\left(\mathrm{CDCl}_{3} ; \mathrm{Me}_{4} \mathrm{Si}\right)$ : $\delta_{\mathrm{H}}-2.62(2 \mathrm{H}, \mathrm{s}$, pyrrole-NH), 7.51-7.70 $(8 \mathrm{H}, \mathrm{m}, \mathrm{Ph}), 7.95-8.07(8 \mathrm{H}, \mathrm{m}, \mathrm{Ph}), 8.66(8 \mathrm{H}, \mathrm{s}, \beta$ pyrrole-H); UV-vis $\left(\mathrm{CH}_{2} \mathrm{Cl}_{2}\right): \lambda_{\max }, \mathrm{nm} 418,514,549,589,645 ; \mathrm{IR}(\mathrm{KBr}): v, \mathrm{~cm}^{-1} 3315$ (w, NH), 1627 (w, C=C), 1349 (m, C=N), 965 (s, NH), 796 (s, CH); Anal. Calcd. for $\mathrm{C}_{44} \mathrm{H}_{26} \mathrm{~N}_{4} \mathrm{Cl}$ : C, 70.27; H, 3.49; N, 7.45; Found: C, 70.65; H, 3.44; N, 7.81.

$\mathbf{T}(\boldsymbol{o}-\mathbf{C l}) \mathbf{P P H}_{2} \cdot \mathrm{T}(o-\mathrm{Cl}) \mathrm{PPH}_{2}$ was synthesized by the same procedures as that descibed for $\mathrm{TPPH}_{2}$ and the final product was recrystallized from $\mathrm{CH}_{2} \mathrm{Cl}_{2}$ to yield $23.7 \%$. ${ }^{1} \mathrm{H} \mathrm{NMR}\left(\mathrm{CDCl}_{3} ; \mathrm{Me}_{4} \mathrm{Si}\right)$ : $\delta_{\mathrm{H}}-2.63(2 \mathrm{H}, \mathrm{s}$, pyrrole-NH), 7.65-7.69 $(4 \mathrm{H}, \mathrm{m}, \mathrm{Ph}), 7.74-7.78(4 \mathrm{H}, \mathrm{m}, \mathrm{Ph}), 7.83-7.88(4 \mathrm{H}, \mathrm{m}$, $\mathrm{Ph}), 8.08-8.25(4 \mathrm{H}, \mathrm{m}, \mathrm{Ph}), 8.71\left(8 \mathrm{H}, \mathrm{s}, \beta\right.$-pyrrole-H); UV-vis $\left(\mathrm{CH}_{2} \mathrm{Cl}_{2}\right): \lambda_{\max }, \mathrm{nm} 412,511,542$, 587, 642; IR(KBr): v, $\mathrm{cm}^{-1} 3325$ (w, NH), 1626 (w, C=C), 1346 (m, C=N), 967 (s, NH), 750 (s, $\mathrm{CH}$ ); Anal. Calcd. for $\mathrm{C}_{44} \mathrm{H}_{26} \mathrm{~N}_{4} \mathrm{Cl}$ : C, 70.27; H, 3.49; N, 7.45; Found: C, 70.05; H, 3.66; N, 7.83.

\section{Acknowledgements}

This work was supported by the Project of the National Natural Science Foundation of China (Grant No. 21206171, 21276006, 21076004 and 21036009), the National High Technology Research and Development Program of China (Grant No. 2012AA063001), the Funding Project for Academic Human Resources Development in Institutions of Higher Learning under the Jurisdiction of Beijing Municipality (Grant No. PHR201107104) and the National Key Technology Research and Development Program of the Ministry of Science and Technology of China (Grant No. 2009BAK61B00).

\section{References}

1. Lindsey, J. S. In The Porphyrin Handbook; Kadish, K. M.; Smith, K. M.; Guilard, R. Eds.; Academic Press: San Diego, 2000; Vol. 1, p 45.

2. Mosinger, J.; Lang, K.; Plistil, L.; Jesenska, S.; Hostomsky, J.; Zelinger, Z.; Kubat, P. Langmuir 2010, 26, 10050. http://dx.doi.org/10.1021/la1001607 PMid:20222692

3. Wang, L. Z.; She,Y. B.; Zhong, R.G.; Ji, H. B.; Zhang, Y. H.; Song, X. F. Org. Process Res. Dev. 2006, 10, 757 . http://dx.doi.org/10.1021/op060056z

4. Zhou, X. T.; Yuan, Q. L.; Ji, H. B. Tetrahedron Lett. 2010, 51, 613. http://dx.doi.org/10.1016/j.tetlet.2009.11.078

5. Wen, W. H.; Lin, M.; Su, C. Y.; Wang, S. Y.; Cheng, Y. S. E.; Fang, J. M.; Wong, C. H. J. Med. Chem. 2009, 52, 4903. http://dx.doi.org/10.1021/jm900515g PMid:19522501 
6. Dunbar, A. D. F.; Brittle, S.; Richardson, T. H.; Hutchinson, J.; Hunter, C. A. J. Phys. Chem. B 2010, 114, 11697. http://dx.doi.org/10.1021/jp102755h PMid:20735119

7. Banerjee, S.; Zeller, M.; Bruckner, C. J. Org.Chem. 2010, 75, 1179. http://dx.doi.org/10.1021/jo9024286 PMid:20067246

8. Silva, A. M. G.; de Oliveira, K. T.; Faustino, M. A. F.; Neves, M. G. P. M. S.; Tome, A. C.; Silva, A. M. S.; Cavalero, J. A. S.; Brandao, P.; Felix, V. Eur. J. Org. Chem. 2008, 4, 704. http://dx.doi.org/10.1002/ejoc.200700852

9. She, Y. B.; Feng, L. S.; Wang, A. X.; Li, X. Y. Chin. J. Chem. Eng. 2008, 16, 369. http://dx.doi.org/10.1016/S1004-9541(08)60090-7

10. Adachi, S.; Nagano, S.; Ishimori, K.; Watanabe, Y.; Morishima, I.; Egawa, T.; Kitagawa, T.; Makino, R. Biochemistry 1993, 32, 241. http://dx.doi.org/10.1021/bi00052a031 PMid:8380334

11. Jia, G. Q.; Feng, Z. C.; Wei, C. Y.; Zhou, J.; Wang, X. L.; Li, C. J. Phys. Chem. B 2009, 113, 16237.

http://dx.doi.org/10.1021/jp906060d PMid:19924868

12. Dipasquale, A. G.; Mayer, J. M.; J. Am. Chem. Soc. 2008, 130, 1812. http://dx.doi.org/10.1021/ja077598w PMid:18198874

13. Maligaspe, E.; Kumpulainen, T.; Lemmetyinen, H.; Tkachenko, N. V.; Subbaiyan, N. K.; Zandler, M. E.; D'Souza, F. J. Phys. Chem. A 2010, 114, 268. http://dx.doi.org/10.1021/jp908115e PMid:19928821

14. Narayanan, S. J.; Sridevi, B.; Chandrashekar, T. K.; Vij, A.; Roy, R. J. Am. Chem. Soc. 1999, $121,9053$. http://dx.doi.org/10.1021/ja991472k

15. Lindsey, J. S.; MacCrum, K. A.; Trhonas, J. S.; Chuang, Y. Y. J. Org. Chem. 1994, 59, 579. http://dx.doi.org/10.1021/jo00082a014

16. Zaidi, S. H. H.; Fico, R. M.; Lindsey, J. S. Org. Process Res. Dev. 2006, 10, 118. http://dx.doi.org/10.1021/op050193g

17. Rothemund, P.; J. Am. Chem. Soc. 1935, 57, 2010. http://dx.doi.org/10.1021/ja01313a510

18. Rothemund, P.; Menotti, A. R. J. Am. Chem. Soc. 1941, 63, 267. http://dx.doi.org/10.1021/ja01846a065

19. Adler, A. D.; Longo, F. R.; Shergalis, W. J. Am. Chem. Soc. 1964, 86, 3145. http://dx.doi.org/10.1021/ja01069a035

20. Adler, A. D. J. Org. Chem. 1967, 32, 476. http://dx.doi.org/10.1021/jo01288a053

21. Longo, F. R.; Finarelli, M. G.; Kim. J. B. J. Heterocyclic Chem. 1969, 6, 927. http://dx.doi.org/10.1002/jhet.5570060625 
22. Lindsey, J. S.; Schreiman, I. C.; Hsu, H. C.; Kearney, P. C.; Marguerettaz, A. M. J. Org. Chem. 1987, 52, 827. http://dx.doi.org/10.1021/jo00381a022

23. Lindsey, J. S.; Wagner, R. W. J. Org. Chem. 1989, 54, 828. http://dx.doi.org/10.1021/jo00265a021

24. Li, F. R.; Yang, K. X.; Tyhonas, J. S.; Maccrum, K. A.; Lindsey, J. S. Tetrahedron 1997, 53, 12339. http://dx.doi.org/10.1016/S0040-4020(97)00770-9

25. Guo, C. C.; He, X. T.; Zhou, G. Y. Chin. J. Org. Chem. 1991, 11, 416.

26. Drain, C. M.; Gong, X. C.; Chem. Commun. 1997, 27, 2117. http://dx.doi.org/10.1039/a704600f

27. Nia, S.; Gong, X. C.; Drain, C. M.; Jurow, M.; Rizvi, W.; Qureshy, M. J. Porphyrins Phthalocyanines 2010, 14, 621. http://dx.doi.org/10.1142/S1088424610002422

28. Gradillas, A.; Campo, C.; Sinisterra, J. V.; Llama, E. F. J. Chem. Soc., Perkin Trans. 1 1995, 2611.

29. Guo, C. C.; Luo, W. P.; Chen, T. Q.; Liu, Q.; Chinese Pat. 2009, CN 20091004341.4.

30. Rocha Gonsalves, A. M. d'A.; Varejao, J. M. T. B.; Pereira, M. M. J. Heterocycl. Chem. 1991, 28, 635.

31. Johnstone, R. A. W.; Nunes, M. L. P. G.; Pereira, M. M.; Rocha Gonsalves, A. M. d'A.; Serra, A. C. Heterocycles 1996, 43, 1423.

32. Serra, A. C.; Rocha Gonsalves, A. M. d'A. Tetrahedron Lett. 2010, 51, 4192. http://dx.doi.org/10.1016/j.tetlet.2010.06.010

33. Toganoh, M.; Hihara, T.; Yonekura, K.; Ishikawa, Y.; Furuta, H. J. Porphyrins Phthalocyanines 2009, 13, 215. http://dx.doi.org/10.1142/S1088424609000292

34. Geier, G. R. III; Ciringh, Y.; Li, F.; Haynes, D. M.; Lindsey, J. S. Org. Lett. 2000,2 , 1745. http://dx.doi.org/10.1021/o1005917h PMid:10880216

35. Koszarna, B. K.; Gryko, D. T. J. Org. Chem. 2006, 71, 3707. http://dx.doi.org/10.1021/jo060007k PMid:16674040

36. Sun, Z. C.; She, Y. B.; Zhong, R. G. Front. Chem. Eng. China 2009, 3, 457. http://dx.doi.org/10.1007/s11705-009-0169-6

37. Sun, Z. C.; She, Y. B.; Zhou, Y.; Song, X. F.; Li, K. Molecules 2011, 16, 2960. http://dx.doi.org/10.3390/molecules16042960 PMid:21471935

38. Geier, G. R. III; Chick, J. F. B.; Callinan, J. B.; Reid, C. G.; Auguscinski, W. P. J. Org. Chem. 2004, 69, 4159. http://dx.doi.org/10.1021/jo0496493 PMid:15176843

39. Mpoukouvalas, K.; Wang, J. J.; Wegner, G. ChemPhysChem. 2010, 11, 139. http://dx.doi.org/10.1002/cphc.200900643 PMid:19998307 
40. Dolphin, D. J. J. Heterocyclic Chem. 1970, 7, 275.

http://dx.doi.org/10.1002/jhet.5570070205

41. Badger, G. M.; Jones, R. A.; Laslett, R. L. Australian Journal of Chemistry 1964, 17, 1028. http://dx.doi.org/10.1071/CH9641028

42. Norman, R. O. C. Principles of organic synthesis; Chapman and Hall: London, 1978; p 680. 